\title{
A study of various chemical pretreatments to fractionate lipids from whey protein phospholipid concentrate
}

\author{
A. V. Swaminathan, ${ }^{1 *}{ }^{*}$ ๑ M. S. Molitor, ${ }^{2} \odot$ K. J. Burrington, ${ }^{2} \odot$ D. Otter, ${ }^{2} \odot$ and J. A. Lucey ${ }^{1,2} \odot$ \\ ${ }^{1}$ Department of Food Science, University of Wisconsin-Madison, Madison 53706 \\ ${ }^{2}$ Center for Dairy Research, University of Wisconsin-Madison, Madison 53706
}

\begin{abstract}
Dairy-derived lipids such as phospholipids (PL) have been gaining interest due to their functional and nutritional properties. Our research goal was to develop a separation process (nonsolvent based) to produce an enriched dairy lipid fraction from whey protein phospholipid concentrate (WPPC). Various chemical pretreatments (i.e., adjustment of $\mathrm{pH}$, calcium, or temperature) were applied to rehydrated commercial WPPC solutions. These treatments were done on a bench-top scale to aid in the precipitation of proteins or PL. The chemically treated solutions were centrifuged and fractionated into the following 3 layers: (1) top fat layer, (2) supernatant in the middle zone, and (3) sediment at the bottom of the centrifuge tubes. The thickness and size of the layers varied with the treatment parameters. Compositional analysis of each layer showed that the proteins, fat, and PL always appeared to fractionate in similar proportions. The proteins in each layer were characterized using sodium dodecyl sulfate-PAGE under reducing and nonreducing conditions. Different proteins including whey proteins, caseins, and milk fat globule membrane proteins and lipoproteins were identified, and no specific type of protein had an affinity for either the top or bottom layer. All types of proteins were present in each of the layers after centrifugation, and there were no major differences in fractionation of the proteins between layers with respect to the chemical treatment applied. The microstructure of protein and fat in WPPC was investigated using confocal laser scanning microscopy. Dual staining of the rehydrated WPPC solution with Fast Green FCF (proteins) and Nile Red (lipids) showed the presence of very large protein aggregates that varied in size from 20 to 150 $\mu \mathrm{m}$, with fat trapped within these aggregates. The confocal laser scanning microscopy images of liquid WPPC revealed fine strands of a weak protein network
\end{abstract}

Received April 5, 2021.

Accepted August 2, 2021.

*Corresponding author: aswaminatha3@wisc.edu surrounding the fat globules. This indicated that there were specific interactions between the proteins, as well as between the fat and proteins in WPPC. Sodium dodecyl sulfate treatment was performed to understand the nature of the interactions between protein and fat. We found that about $35 \%$ of the fat present in WPPC was in the form of free fat, which was only physically entrapped within the protein aggregates. The remaining fat had some form of association with the proteins in WPPC. Other fractionation techniques would be needed to obtain an enriched dairy lipid fraction.

Key words: whey protein phospholipid concentrate, chemical pretreatment, phospholipid

\section{INTRODUCTION}

Whey protein phospholipid concentrate (WPPC) is a co-product of the whey protein isolate (WPI) production process, and it is the retentate fraction of the microfiltration (MF) of cheese whey. Production of WPI in the United States increased from 29,000 to 50,000 t between 2012 and 2016 (USDEC, 2018). With increased production of WPI, the generation of WPPC is also increasing. The WPPC is a very underutilized dairy ingredient in the food industry and is mainly used as animal feed.

As an ingredient rich in protein, fat, and phospholipid (PL), WPPC could be used for its functionality (e.g., emulsification, foamability, water holding capacity) in many value-added food applications, such as protein bars, processed cheese, ice cream, and beverages. Bund and Hartel (2013) evaluated various blends of WPPC and delactosed permeate for applications in ice cream as a source of protein and fat. Ice cream with NDM as a protein source was used as a control. They found that all the ice creams had similar mean ice crystal size. The highest melt rate and decreased fat destabilization was observed in WPPC with delactosed permeate blends compared with the control. Another study focused on evaluating the performance of WPPC in ice cream, caramels, and cakes (Levin et al., 2016a). The WPPC was used to replace synthetic chemical emulsifiers in 
ice cream, sweetened condensed milk (i.e., the protein source) in caramels, and whole eggs in cakes. Ice cream made with WPPC had lower overrun, higher melt rate, and similar ice crystal and air cell sizes compared with the control. In caramels, a large increase in cold flow and a decrease in hardness and stickiness was observed in samples made with WPPC compared with control samples. In cakes, replacing whole eggs with WPPC had similar yields compared with the control cakes made with whole eggs, but the volume and the contour of the test cakes were lower than the control. Overall, it was found that WPPC can be used for the partial replacement of eggs and synthetic emulsifiers in cakes and ice cream, but not in caramels. The functionality of WPPC in food products were variable because of the variability in composition between WPPC powders. For this reason, it was believed that isolating the PL from WPPC could create 2 unique ingredients (protein and $\mathrm{PL}$ ) that were more functional than the original WPPC. Phospholipids are known for their emulsification properties. Zhu and Damodaran (2013) extracted dairy lipids from cheese whey and studied their emulsifying properties at different concentrations. Emulsions made with greater than $4 \%$ dairy lipids were found to be very stable for more than $60 \mathrm{~d}$ at room temperature.

Other than functionality applications, WPPC can also be used for nutrition-based applications, such as infant formula. Human milk serves as a basis of development for designing infant formula. Phospholipids are some of the important human milk nutrients that play a vital role in growth and brain development in newborn infants. The types of PL in bovine milk are similar to the ones present in human milk, although concentrations vary (Cilla et al., 2016). Hence, PL from the milk source, such as the ones present in WPPC, could be used as an ingredient in infant formula. Several commercial dairy products enriched in phospholipids, such as SureStart MFGM Lipid 100 and SureStart MFGM Lipid 70 (Fonterra Co-operative Group Ltd.), Lacprodan PL-20 and Lacprodan MFGM-10 (Arla Foods Ingredients), and Enfamil NeuroPro infant formula (Mead Johnson and company, LLC) are already available in the market with different levels of PL.

The need to fractionate lipids from proteins began when whey proteins were first isolated for their versatile functionality (Maubois et al., 1987). Typically, cheese whey contains $<0.4$ to $0.5 \%$ of residual milk lipids consisting of small fat globules, lipoprotein particles, and milk fat globule membrane (MFGM) fragments. A simple clarification step is not enough to remove all these residual lipids as they have different densities, and the clarified whey can have up to $0.2 \%$ residual lipids. Kamath and Morr (1997) fractionated, identified, and quantified the different types of residual lipids in Swiss cheese whey (SCW). Three distinct zones were obtained after centrifugation of SCW as follows: (1) a top, turbid zone that contained the smallest sized residual milk fat globules, also called as the low-density lipid fraction, (2) a clear middle zone that contained the medium-density lipid fraction, and (3) a small, gelatinous pellet that formed on the bottom of the tube that contained the high-density lipid fraction. The majority of proteins and PL were found in the high-density lipid fraction, suggesting that it mainly comprised phospholipoprotein complexes, whereas the low-density lipid fraction consisted mainly of neutral lipids. These residual lipids are concentrated along with the proteins during the UF process used for the manufacture of WPC products, and they result in impaired functionality and contribute to off-flavor development. These residual lipids can also cause increased whey turbidity and a decline in the flux during membrane processing of whey (Maubois, 1984).

To overcome these problems, cheese whey pretreatment methods have been implemented to remove residual lipids from whey (Maubois et al., 1987). Over the years, various chemical pretreatment methods for delipidation were developed by exploiting the different physical or chemical properties of the residual lipids. The sludge (separated residual lipids) from these pretreatments are of potential interest as they contain PL, which has functional, nutritional, and healthpromoting properties (Morr and Ha, 1993; Rombaut and Dewettinck, 2007). Research is currently underway to fractionate and concentrate PL material from these lipid rich dairy streams (Price et al., 2018; Huang et al., 2020). Buttermilk, butter serum, and WPPC are the most researched dairy materials for extraction of PL as they have higher concentrations of PL and they are also underutilized dairy ingredients.

Our objective was to evaluate previously used (nonsolvent) methods that have been successful for the chemical pretreatment of whey [e.g., isoelectric precipitation as performed by Donovan and Mulvihill (1987), calcium-induced whey protein aggregation as described by Riou et al. (2011), and thermocalcic aggregation as described by Maubois et al. (1987)] for the removal of lipids from WPPC. These methods were applied to WPPC on a bench-top scale to fractionate dairy lipids, and the yield and recovery of each fraction from these treatments were evaluated.

\section{MATERIALS AND METHODS}

\section{Materials}

Whey protein phospholipid concentrate powder and the whey MF feed were obtained from Agropur Inc. 
Liquid WPPC (WPPC before spray drying) was obtained from Agropur Inc. and Grande Cheese Company. The WPPC powders were stored at room temperature, whereas the liquid WPPC and whey MF feed were refrigerated $\left(4^{\circ} \mathrm{C}\right)$. Soy lecithin used for the total PL analysis was purchased from Premier Research Labs. All of the chemicals used were purchased from Sigma, Fisher Scientific, and Bio-Rad Laboratories.

\section{Compositional Analyses}

Compositional analysis and chemical pretreatment experiments were performed on rehydrated WPPC solutions. The WPPC powder was dispersed by stirring the solution at room temperature for $2 \mathrm{~h}$ and allowing the solution to rehydrate overnight at $4^{\circ} \mathrm{C}$. The total protein, fat, ash, and moisture of WPPC were determined according to standard AOAC methods (AOAC International, 2000).

\section{Total PL Analysis}

Lipid extraction was carried out using a modified Mojonnier procedure (AOAC International, 2000). Six grams of WPPC sample was used for lipid extraction. To improve the recovery of PL, $1.5 \%$ (wt/wt) of $\mathrm{NaCl}$ was added to the sample (Walstra and de Graaf, 1962). Digestion was applied to liberate phosphorus from the extracted fat using a modified method as described by Walstra and de Graaf (1962). The extracted fat was rinsed into a Kjeldahl digestion flask using ethyl ether. The solvent was evaporated by placing the digestion flask on a Kjeldahl Micro Digestor digestion unit (Labconco) and heating at $70^{\circ} \mathrm{C}$ until the fat sample was completely dried. We added $10 \mathrm{~mL}$ of concentrated $\mathrm{HNO}_{3}(16 \mathrm{M})$ and $5 \mathrm{~mL}$ of concentrated $(18 \mathrm{M})$ $\mathrm{H}_{2} \mathrm{SO}_{4}$ to the flask. The flask was again heated on the heating unit at $250^{\circ} \mathrm{C}$ until the contents in the flask turned clear or slightly yellow, indicating the end of the digestion. The total digestion time was between 2 and $4 \mathrm{~h}$, depending on the amount of fat being digested. The contents of the flask were rinsed into a $100-\mathrm{mL}$ graduated flask and made up to volume with deionized water.

Phosphorus content was determined using the colorimetric method as described by Walstra and de Graaf (1962). A standard curve was constructed using the solutions containing phosphorus concentrations between 0 and $5 \mu \mathrm{g} / \mathrm{mL}$ in solution. The equation obtained from this standard curve $(\mathrm{y}=0.1325 \mathrm{x}-0.0003$, where $\mathrm{y}=$ absorbance measured using spectrophotometer and $\mathrm{x}$ = unknown phosphorus value) was used to calculate the phosphorus content in the samples. The phosphorus content in the samples was converted to phospholipid content by using a conversion factor of 26 . A test was conducted to determine the recovery of PL using this method. A known amount of PL from soy lecithin was extracted and digested using the procedure described above. After the spectrophotometric test, it was found that the recovery of PL was $\sim 90 \%$. This recovery test was repeated 6 times.

Compositional analysis of the type of PL present in WPPC was performed by ALS Marshfield LLC, a testing laboratory located in Marshfield, Wisconsin. They used the Folch method (Folch et al., 1957) to extract the lipids from WPPC followed by solid-phase extraction clean up to remove the neutral lipids from the extracted fat. Normal phase HPLC analysis using a stationary silica-based column and dichloromethane based mobile phase along with an evaporative light scattering detector was used to identify and quantify each of the PL present in WPPC. The laboratory used Avalli and Contarini (2005) and Le et al. (2011) as references in developing the final assay.

\section{Characterization of WPPC}

Particle Size Analysis. A Malvern Mastersizer 2000S particle size analyzer (Malvern Instruments Ltd.) was used to measure the particle size distribution and volume-weighted mean diameter $\left(\mathbf{D}_{4.3}\right)$ of $5 \%$ rehydrated WPPC samples and liquid WPPC. The Mastersizer used a laser diffraction technique to measure the size of the particles, water was used as the dispersant, and measurements were collected in duplicate.

Qualitative SDS-PAGE Analysis. The SDSPAGE analysis was used to identify the type and form of proteins present in rehydrated WPPC samples. The protein concentrations in the samples were adjusted to $2 \mathrm{mg} / \mathrm{mL}$, and they were diluted to a final concentration of $1 \mathrm{mg} / \mathrm{mL}$, with and without 2-mercaptoethanol. The prepared solution was heated in a boiling water bath for 3 min. Precast 4 to 20\% Mini-Protean TGX gels with a $10 \times$ Tris/Glycine/SDS buffer (Bio-Rad Laboratories) were used for analysis. Fifteen microliters of sample was loaded into each lane, and $5 \mu \mathrm{L}$ of SDS-PAGE broad range protein standard (Bio-Rad Laboratories) was used as a molecular weight standard. Electrophoresis was performed at $200 \mathrm{~V}$ for $30 \mathrm{~min}$ and the gels were stained with Coomassie Blue R-250 (BioRad Laboratories). The gels were later destained with deionized water and scanned using an Epson Perfection V600 Photo scanner (Epson America Inc.).

Confocal Laser Scanning Microscopy. Sample preparation for confocal laser scanning microscopy (CLSM) observations was performed as described by Gallier et al. (2010). Rehydrated WPPC samples were double stained with Nile Red (2:100, vol/vol) and Fast 
Green FCF (6:100, vol/vol) to stain for fat and protein, respectively. The stains were added to the WPPC samples in centrifuge tubes, the solutions were vortexed, and then they rested for $20 \mathrm{~min}$. We deposited $25-\mu \mathrm{L}$ samples onto the slides using a pipette, and a coverslip was applied onto the samples without excessive pressure. The prepared slides were left undisturbed for 10 min to ensure proper contact between the coverslip and the slide.

A Nikon A1 R+ confocal laser scanning microscope (Nikon Instruments Inc.) was used to look at the microstructure of protein and fat in WPPC samples. The CLSM is equipped with 4 lasers, allowing the excitation of several fluorescent probes at the same time. A $100 \times$ oil-immersion objective was used for all images. Excitation of Nile Red and Fast Green FCF stains were at 633 and $488 \mathrm{~nm}$, respectively. At least 5 images were obtained per slide by scanning the sample across a defined section along the $\mathrm{x}$ - and $\mathrm{y}$-axes. All images were acquired at room temperature and the images were processed using Fiji (Laboratory of Optical and Computational Instrumentation, UW-Madison, WI), an open-source software on ImageJ [Java 1.8.0_172 (64bit)], an image-processing domain (National Institute of Health).

Apparent Viscosity Testing of Liquid WPPC. The shear rate sweep test was performed to determine the apparent viscosity of liquid WPPC. Samples were loaded into the Anton Paar Physica rheometer MCR 301 (Anton Paar), and the system temperature was set to $20^{\circ} \mathrm{C}$. The test used a cup and bob geometry with diameters of 28.9 and $26.6 \mathrm{~mm}$, respectively. The sample was then subjected to an increasing shear rate (log scale), from 0 to $100 \mathrm{~s}^{-1}$, at $20^{\circ} \mathrm{C}$.

Bench-Scale Trials of Chemical Pretreatment Methods. Appropriate quantities of WPPC powder were dissolved in Milli-Q water to prepare 5 and $10 \%$ (wt/vol) WPPC solutions. These solutions were stirred for $2 \mathrm{~h}$ at room temperature using a magnetic stirrer and later refrigerated at $4{ }^{\circ} \mathrm{C}$ for overnight rehydration. Experiments were performed on these solutions the following day after bringing the temperature of the solution to $21^{\circ} \mathrm{C}$ by immersion in water bath. All chemical pretreatments were repeated twice $(\mathrm{n}=2)$, and the analysis was done in duplicate for each trial. After each chemical pretreatment was performed, the solutions fractionated into the following 3 layers: low-density, medium-density, and high-density fraction. Each layer was collected carefully, and compositional analysis (total protein, fat, and PL) was performed on each of these layers to determine both the extent of protein precipitation and how the fat fractionated between these layers. The low-density fraction, except for the SDS treatment, contained broken pieces of floating fat, and hence could not be collected separately. Therefore, the medium-density fraction along with the low-density fraction was considered as the top layer, and the highdensity fraction as the bottom layer. A mass balance was performed to demonstrate the partitioning of the different WPPC components.

Isoelectric Precipitation of Whey Proteins. Hydrochloric acid $(1 N$ and $0.1 N$ ) was slowly added to the $10 \%$ WPPC solution to reach final $\mathrm{pH}$ values of 4.8 and 5.2 while the solution was being stirred at room temperature $\left(\sim 20^{\circ} \mathrm{C}\right.$; Donovan and Mulvihill, 1987). The initial WPPC solution was the control sample and had a $\mathrm{pH}$ value of 6.2 . These solutions were stirred at room temperature for $15 \mathrm{~min}$ after the $\mathrm{pH}$ adjustment and then centrifuged at $2,000 \times g$ at $25^{\circ} \mathrm{C}$ for $60 \mathrm{~min}$.

Thermocalcic Aggregation. The effect of temperature and calcium concentration on the precipitation of PL (present in lipoproteins and MFGM fragments) from 5\% WPPC was studied as mainly described by Maubois et al. (1987). Different levels of calcium chloride $(0,8$, or $30 \mathrm{mM})$ were added to the rehydrated WPPC solution while stirring, and the formation of calcium phosphate complexes were visually monitored. The $\mathrm{pH}$ was later adjusted to $7.3 \mathrm{using} 1 \mathrm{~N}$ sodium hydroxide, and the solution was rapidly heated to 50 or $80^{\circ} \mathrm{C}$ in a water bath and held for $30 \mathrm{~min}$. It was then centrifuged at $1,000 \times g$ at $25^{\circ} \mathrm{C}$ for $10 \mathrm{~min}$. This treatment was aimed at precipitating phospholipids utilizing the property of calcium phosphate precipitation above $\mathrm{pH} 7$.

Heat and Calcium-Induced Aggregation of Whey Proteins. To analyze the extent of whey protein aggregation and precipitation, experiments as described by Riou et al. (2011) were performed. Appropriate levels of calcium chloride $(0,8$, or $30 \mathrm{mM})$ were added to $5 \%$ WPPC solutions while being stirred. The calcium salts in this treatment were added to aid in the precipitation of whey proteins. The $\mathrm{pH}$ of the solution was adjusted to 4.8 using hydrochloric acid $(0.1$ and $1 \mathrm{M})$, after which the solutions were heated in a water bath for 30 min at 2 different temperatures $\left(50\right.$ or $80^{\circ} \mathrm{C}$ ). The heated solutions were then allowed to cool to room temperature before being centrifuged at $1,000 \times g$ at $25^{\circ} \mathrm{C}$ for $10 \mathrm{~min}$.

SDS Treatment. Sodium dodecyl sulfate is an anionic detergent that coats proteins and provides them with a uniform negative charge, which inhibits proteinprotein association. It is widely used in PAGE as it allows separation based on molecular weight only (i.e., it is not affected by the intrinsic charge of the protein). The SDS treatment aided in the separation of protein and fat and to quantify the amount of "free fat" (i.e., physically entrapped by the protein aggregates) present in WPPC. We added SDS at various concentrations (0, 
Table 1. Composition of industry whey phospholipid concentrate (WPPC) powders compared with the American Dairy Products Institute (ADPI) standard and reported values

\begin{tabular}{lclc}
\hline Composition & WPPC powder $^{1}$ & ADPI standard & WPPC powder \\
\hline Protein (\%) & $60.50 \pm 0.03$ & Minimum 50 & $50.26-69.97$ \\
Fat (\%) & $31.80 \pm 1.72$ & Minimum 12 & $10.85-38.11$ \\
Ash (\%) & $1.88 \pm 0.04$ & Maximum 8 & $1.88-4.08$ \\
Moisture (\%) & $2.00 \pm 0.04$ & Maximum 6 & $1.90-4.78$ \\
Phospholipid (as \% of fat) & $17.6 \pm 1.3$ & Not applicable & Not analyzed \\
\hline
\end{tabular}

${ }^{1}$ Values are average $( \pm \mathrm{SD})$ of results obtained from 3 different WPPC powder samples from the same supplier $(\mathrm{n}=3)$.

${ }^{2}$ Proximate range of composition of WPPC powders obtained from 4 different suppliers $(\mathrm{n}=2)$ as reported by Levin et al. (2016b).

$0.5,1,2,5$, or $10 \%)$ to $5 \%$ WPPC solution. We believe that SDS should disperse simple protein aggregates (but without breaking covalent bonds such as disulfide). This mixture was stirred for $1 \mathrm{~h}$ at room temperature. Confocal microscopy was used to visually determine if the protein and fat separated in the samples. Two SDS concentrations [1 and 5\% (wt/wt) protein] were chosen to quantitively measure the amount of free fat fractionated on top of the solution after centrifugation of the treated sample. Samples were centrifuged at 2 speeds $(2,400$ and $16,300 \times g)$ to see if the centrifugation speeds caused a difference in the amount of free fat that was fractionated.

\section{Statistical Analysis}

A randomized, unblocked design was used for analysis of the response variables relating to each chemical pretreatment. We performed ANOVA using the PROC GLM procedure of SAS (version 9.1; SAS Institute). Tukey's test was used to evaluate the effect of pretreatment and the interactions between the different parameters on the fractionation of protein and fat from WPPC. An effect was considered significant at $P<$ 0.05 .

\section{RESULTS AND DISCUSSION}

\section{Composition of WPPC}

The composition of WPPC powder and the American Dairy Products Institute (ADPI) standard for WPPC is presented in Table 1. This WPPC powder met the requirements of an industry standard established by American Dairy Products Institute (2015). Similar results were reported by Levin et al. (2016b), who analyzed the composition of several WPPC powders obtained from different suppliers and 2 lots from the same supplier obtained 6 mo apart. Levin et al. (2016b) showed that there were major differences in the composition of the various WPPC samples, even though they were all within the range of the standard established by the ADPI. These differences in composition between WPPC powders obtained from various suppliers can be due to the subtle differences in composition of the initial cheese whey source that gets magnified when the whey is concentrated $\sim 100$ fold during the membrane filtration process (affected by parameters such as pressure, temperature, flux, membrane material, and pore size) involved in the production of the WPI. We expect the WPPC powders to have different proteins when compared with WPI, with a majority of the proteins being whey proteins (mostly denatured because the native proteins would pass through the MF membrane), a few CN and MFGM proteins and lipoproteins, and different lipids such as neutral lipids (triglyceride, diglycerides, monoglycerides, cholesterol) and polar lipids [i.e., PL as observed by Levin et al. (2016b)].

\section{Total PL Content and PL Composition in the WPPC Powder}

The total PL content in the WPPC powder was 17.6 $\pm 1.3 \%$ (as a percentage of total lipids; \pm SD). Price et al. (2018) reported PL was $29.1 \%$ of total lipid in their liquid WPPC sample. The difference in total PL content between WPPC samples could be due to the differences in the initial whey composition and the manufacturing processes involved in the production of WPI, and differences in the analysis methods used to measure the fat (Folch vs. Röse Gottlieb) and total PL (phosphorus assay, HPLC, phosphorus-nuclear magnetic resonance) content in the WPPC samples. Barry et al. (2016) showed that a difference in fat extraction methods (i.e., Röse Gottlieb or Folch) can lead to a difference in the total PL extracted. Buttermilk and butter serum, which are considered to be good source material for PL extraction, have PL contents of 25 and $15 \%$ (as $\%$ lipid), respectively (Rombaut and Dewettinck, 2006, 2007). Our WPPC sample had approximately 18\% PL (as \% lipid), which indicated that WPPC was also a good source for dairy PL extraction. 
Table 2. Composition of phospholipid (PL) present in whey protein phospholipid concentrate (WPPC) sample $(\mathrm{n}=2)$

\begin{tabular}{lccc}
\hline PL class & $\begin{array}{c}\text { WPPC } \\
(\mathrm{mg} / \mathrm{g} \text { of powder })\end{array}$ & $\begin{array}{c}\text { WPPC } \\
\text { (\% of total PL) }\end{array}$ & $\begin{array}{c}\text { Bovine milk } \\
\text { (\% of total PL) }\end{array}$ \\
\hline Phosphatidylcholine & 24.40 & 31.5 & 27.3 \\
Phosphatidylethanolamine & 21.55 & 27.8 & 32.3 \\
Sphingomyelin & 20.56 & 26.6 & 20.5 \\
Phosphatidylserine & 6.88 & 8.9 & 10.5 \\
Phosphatidylinositol & 4.00 & 5.2 & 9.3 \\
Total PL & 77.39 & & \\
\hline
\end{tabular}

${ }^{1}$ Results from Avalli and Contarini (2005) on bovine milk.

The results of the compositional analysis of PL (Table 2) showed that all 5 major PL [phosphatidylcholine (PC), phosphatidylethanolamine (PE), sphingomyelin (SM), phosphatidylinositol (PI), and phosphatidylserine (PS)] were present in the WPPC sample, as expected for any products made from bovine milk. Higher proportions of PC, PE, and SM types of PL were found in WPPC with lower proportions of PI and PS. Similar proportions of individual PL species were reported by Rombaut and Dewettinck (2007) and Vaghela and Kilara (1996) (i.e., PC, PE, and SM ranged from around 20 to $30 \%$, and PI and PS around 5 to $15 \%$ as $\%$ total PL).

\section{Characterization of WPPC}

CLSM Images of WPPC Before and After Spray Drying. The dual staining of proteins and fat in $5 \%$ rehydrated WPPC solution showed that there were large protein aggregates, with most of the fat entrapped within these aggregates (Figure 1). The size of these aggregates greatly varied from 20 to $150 \mu \mathrm{m}$. Gallier et al. (2010) made similar observations in reconstituted buttermilk powder (BMP). Large protein aggregates, 15 to $30 \mu \mathrm{m}$ in size, with some lipid vesicles within the aggregates were visible in their buttermilk powder samples (Gallier et al., 2010). Auty et al. (2001) studied the distribution of protein and fat in cheese and milk powders. They found that whole milk powders that were spray dried were in the form of rounded particles occluded with protein, fat, and air. The fat trapped within the WPPC powder particles appear somewhat similar to high-fat-encapsulated spray dried powders. This type of encapsulation in a manufacturing process of high-fat powder is achieved by the homogenization step before spray drying or in the atomization step during spray drying.

Figure 2 shows the CLSM images of 2 liquid WPPC samples from different suppliers. Clusters, or strands, of protein aggregates surrounding fat were present in liquid WPPC, and the microstructure resembles that of a weak gel network (e.g., as observed by Nguyen et al., 2014). This observation suggested that there were some interactions between proteins in liquid WPPC, that helped to entrap fat even before the spray drying process. The atomization of the liquid WPPC before spray drying could have increased the amount of the fat entrapped within these protein aggregates.

Particle Size Analysis. The particle size distribution of liquid WPPC (Figure $3 \mathrm{~b}$ ) exhibited 3 peaks at around $0.18,0.8$, and $5.7 \mu \mathrm{m}$. Similar size distribution profiles were observed by Gassi et al. (2016) for liquid butter serum. They suggested that these peaks can correspond to $\mathrm{CN}$ micelles, vesicles of $\mathrm{PL}$ or protein aggregates, and small fat globules, respectively. The mean diameter $\left(\mathrm{D}_{4,3}\right)$ of the particles shifted to around $40 \mu \mathrm{m}$ in the rehydrated WPPC solutions, with particle size distribution ranging from 0.8 to $150 \mu \mathrm{m}$ (Figure $3 a)$. No very distinguishable large aggregates around the size of the $\mathrm{D}_{4,3}$ was observed in the liquid WPPC sample from CLSM observations (Figure 2); the reason may be these weak aggregates were dispersed by the dilution and stirring used for particle size analysis.

Apparent Viscosity of Liquid WPPC. The apparent viscosity of liquid WPPC slightly increased initially with an increase in shear rate as shown in Figure 4 before structural breakdown occurred. This curve resembled that of a yogurt gel, similar to the trends were reported by Lee and Lucey (2006). They attributed the behavior in the very low shear rate region to the presence of a weak yield stress. Once the yield stress value was exceeded, the apparent viscosity of liquid WPPC steadily decreased from around 100 to $0.8 \mathrm{~Pa} \cdot \mathrm{s}$; therefore, it exhibited shear thinning. These results indicated that the system initially behaved similar to a weak gel, suggesting that there were some weak interactions between the components in the initial sample. This was also confirmed using a low amplitude oscillatory rheology test, which showed that the storage moduli $\left(\mathbf{G}^{\prime}\right)$ values were greater than loss moduli $\left(\mathbf{G}^{\prime \prime}\right)$ values, and loss tangent values were less than 1 when tested at a frequency of $0.1 \mathrm{~Hz}$ and strain of $0.2 \%$ (results not shown), thus confirming the presence of weak gel network in the liquid WPPC sample. 
SDS-PAGE Profiles. The SDS-PAGE profiles of MF feed (used for WPI production) and liquid WPPC in comparison with 5\% rehydrated (from dried) WPPC solution are shown in Figure 5a and 5b under nonreducing and reducing conditions, respectively. The MF feed (Figure 5a; lane 2) contained predominantly whey proteins, including $\beta$-LG and $\alpha$-LA with minor amounts of MFGM proteins and CN compared with the rehydrated WPPC solution (Figure 5a; lane 1). Presumably these $\mathrm{CN}$ were serum or soluble $\mathrm{CN}$. Under reducing conditions, there was an increase in the intensity of $\beta-\mathrm{LG}$ band and the MFGM bands in all the samples (Figure $5 \mathrm{~b})$. This could be due to the interactions between the MFGM proteins and $\beta-L G$ via the sulfhydryl-disulfide interchange reaction. The rehydrated WPPC (Figure 5a; lane 1) and liquid WPPC (Figure 5a; lane 3) had similar protein bands. Both types of WPPC had higher amounts of unresolved high molecular weight proteins compared with the MF feed. This indicated that higher amounts of denatured proteins were found in WPPC, probably due to the size of these large aggregates they were retained (concentrated) in the MF retentate.

\section{Bench-Scale Trials of Different Chemical Pretreatments on WPPC}

Isoelectric Precipitation of Whey Proteins. All the samples, including the control, fractionated into 3 layers after centrifugation. This kind of fractionation was also observed in SCW and buttermilk by Kamath
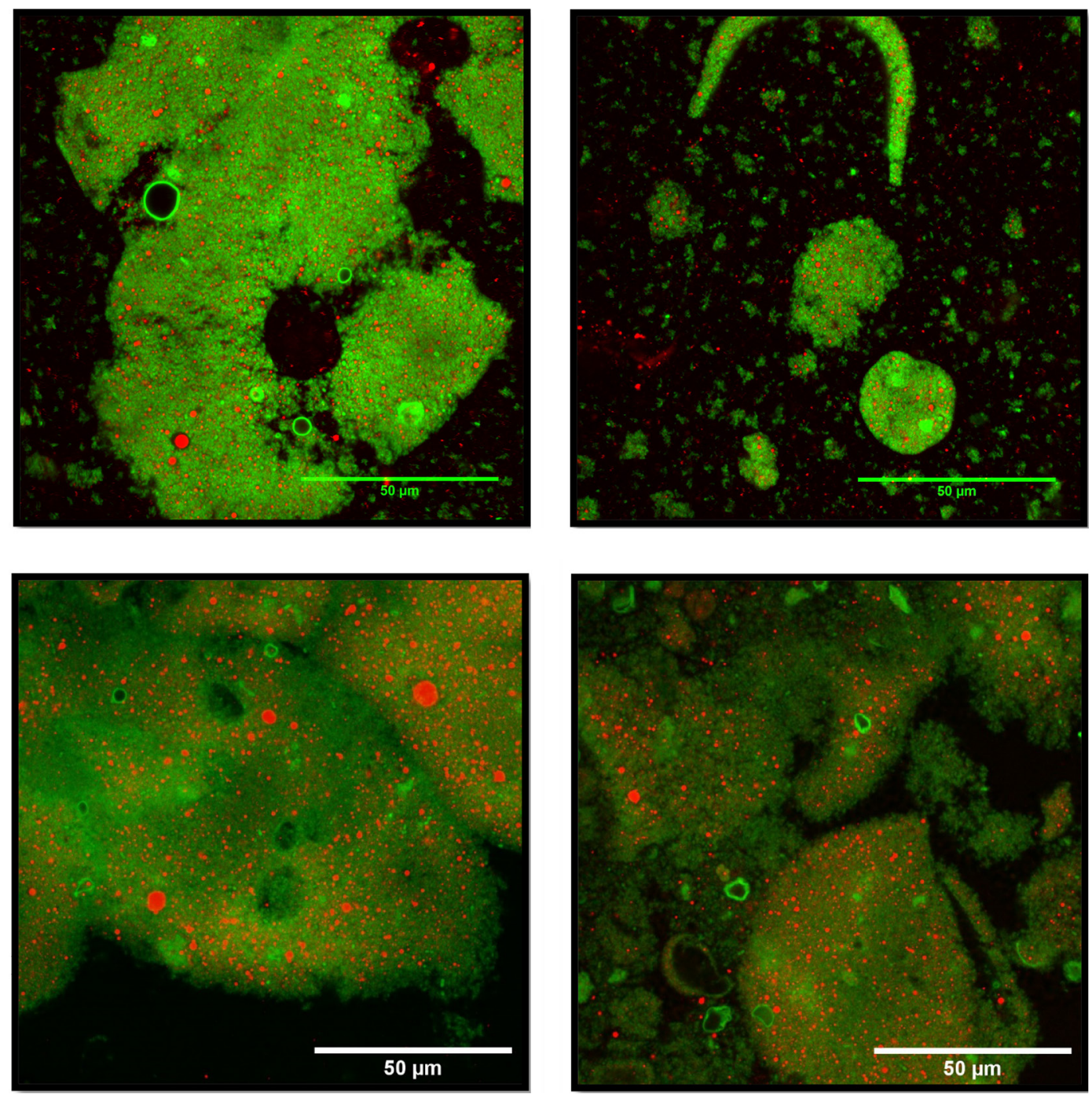

Figure 1. Various confocal laser scanning microscopy images of rehydrated $5 \%$ whey protein phospholipid concentrate solution (stirred for $2 \mathrm{~h}$ at room temperature and rehydrated overnight at $4^{\circ} \mathrm{C}$ ). Scale bar $=50 \mu \mathrm{m}$. Proteins are stained green with Fast Green FCF, and lipids are stained red with Nile Red. 
and Morr (1997) and Gauvin et al. (2018), respectively. In our analysis, the low-density fraction was difficult to separate from the medium-density fraction because it contained broken fragments of fat. Hence, the mediumdensity fraction, along with the low-density fraction, was considered as the top layer. The composition of protein, fat, and PL in the different layers are shown in Table 3. Approximately 20 to $25 \%$ of the protein, fat, and PL sedimented (high-density fraction), and the remaining 75 to $80 \%$ of these components partitioned into the top layer for all the samples. The proteins sedimented more as the $\mathrm{pH}$ decreased from 6.2 ( $\mathrm{pH}$ of control sample) to 4.8 , but it was not as large a change as we expected it to be. This result was surprising because the solubility of denatured whey proteins should be lowest near its isoelectric point (the isoelectric point range for $\beta-\mathrm{LG}$, $\alpha-L A$, and bovine serum albumin are 5.1-5.3, 4.2-4.5, and 4.5-5.0, respectively). Minimum electrostatic repulsion is observed at the isoelectric point leading to protein-protein interaction, aggregation, and precipitation of whey proteins (Pelegrine and Gasparetto, 2005). The $\mathrm{pH}$ value did not have a significant effect on lipid and PL partitioning in the WPPC solution.

Thermocalcic Aggregation ( $p H$ 7.3). All the WPPC solutions fractionated into 3 layers before and after thermocalcic aggregation treatment. The lowdensity fraction had broken fragments of fat, similar to what was observed in the isoelectric precipitation process, and hence the medium-density fraction along with the low-density fraction was considered as the top layer. The effect of calcium concentration and temperature on the precipitation of protein, fat, and PL in WPPC solutions is presented in Table 3. It was clear from the results that a higher temperature $\left(80^{\circ} \mathrm{C}\right)$
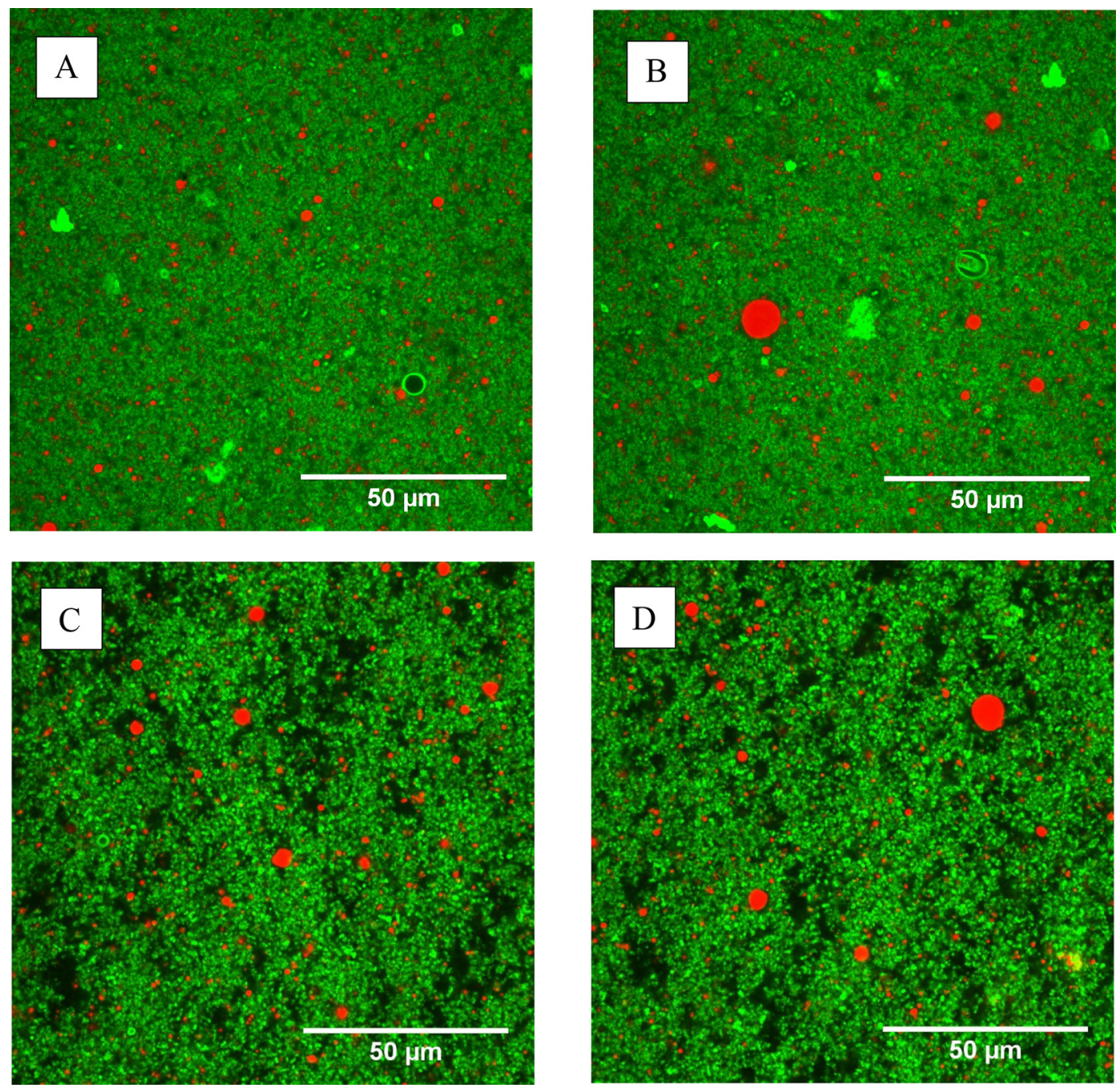

Figure 2. Confocal laser scanning microscopy images of liquid whey protein phospholipid concentrate solution from manufacturer 1 (A, B) and manufacturer $2(\mathrm{C}, \mathrm{D})$. Scale bar $=50 \mu \mathrm{m}$. Proteins are stained green with Fast Green FCF, and lipids are stained red with Nile Red. 

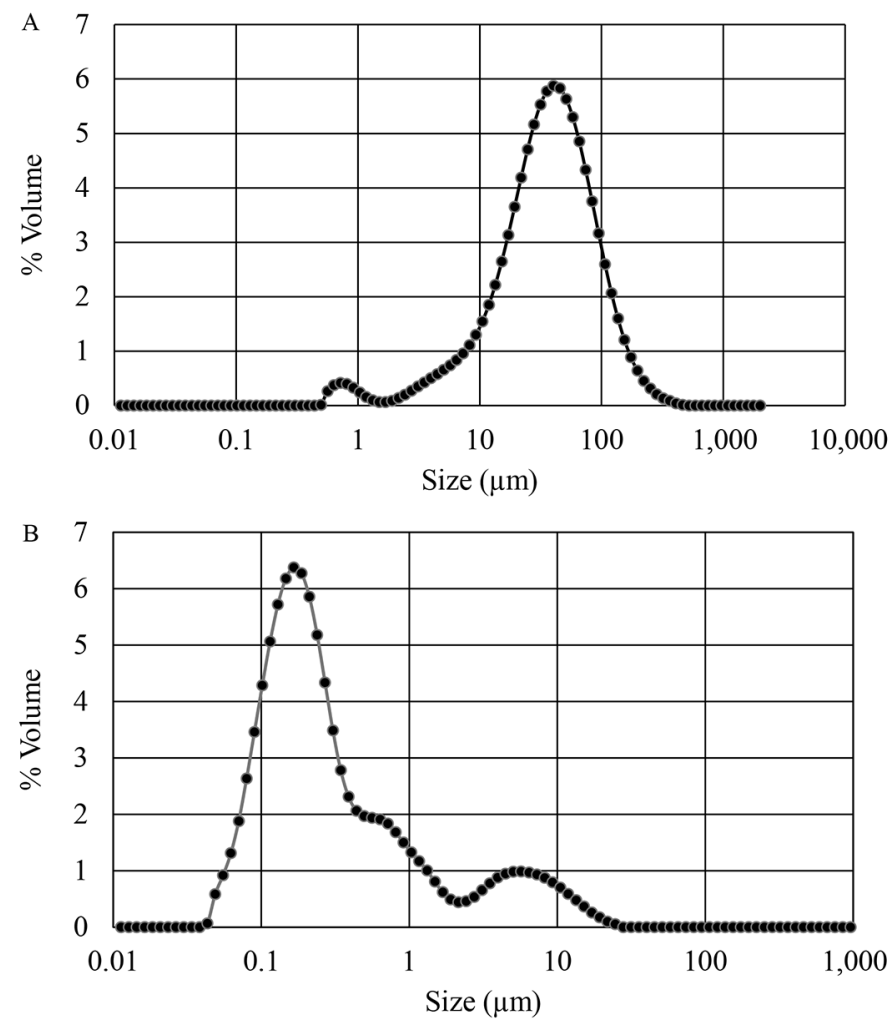

Figure 3. Particle size distribution of (A) rehydrated 5\% whey protein phospholipid concentrate solution (WPPC; stirred for $2 \mathrm{~h}$ and rehydrated overnight at $4^{\circ} \mathrm{C}$ ) and (B) liquid WPPC.

and higher calcium levels $(30 \mathrm{~m} M)$ had a major effect on precipitating the PL, protein, and lipids. With an increase in calcium concentration, there was a significant increase in PL content in the sediment compared with the control, especially at high temperatures. At $50^{\circ} \mathrm{C}$, the PL content in the sediment of the control was approximately $13 \%$, and it increased to approximately

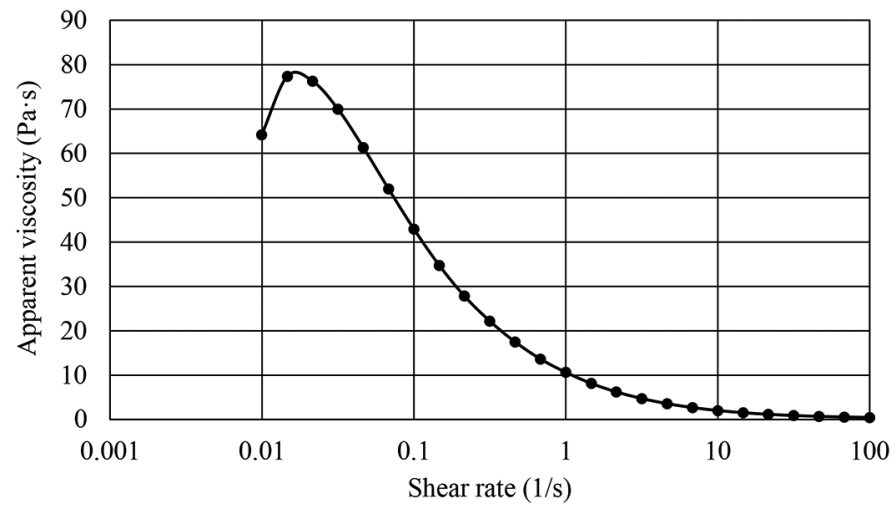

Figure 4. Apparent viscosity of liquid whey protein phospholipid concentrate as a function of shear rate (measured in duplicate, $\mathrm{n}=2$ ).
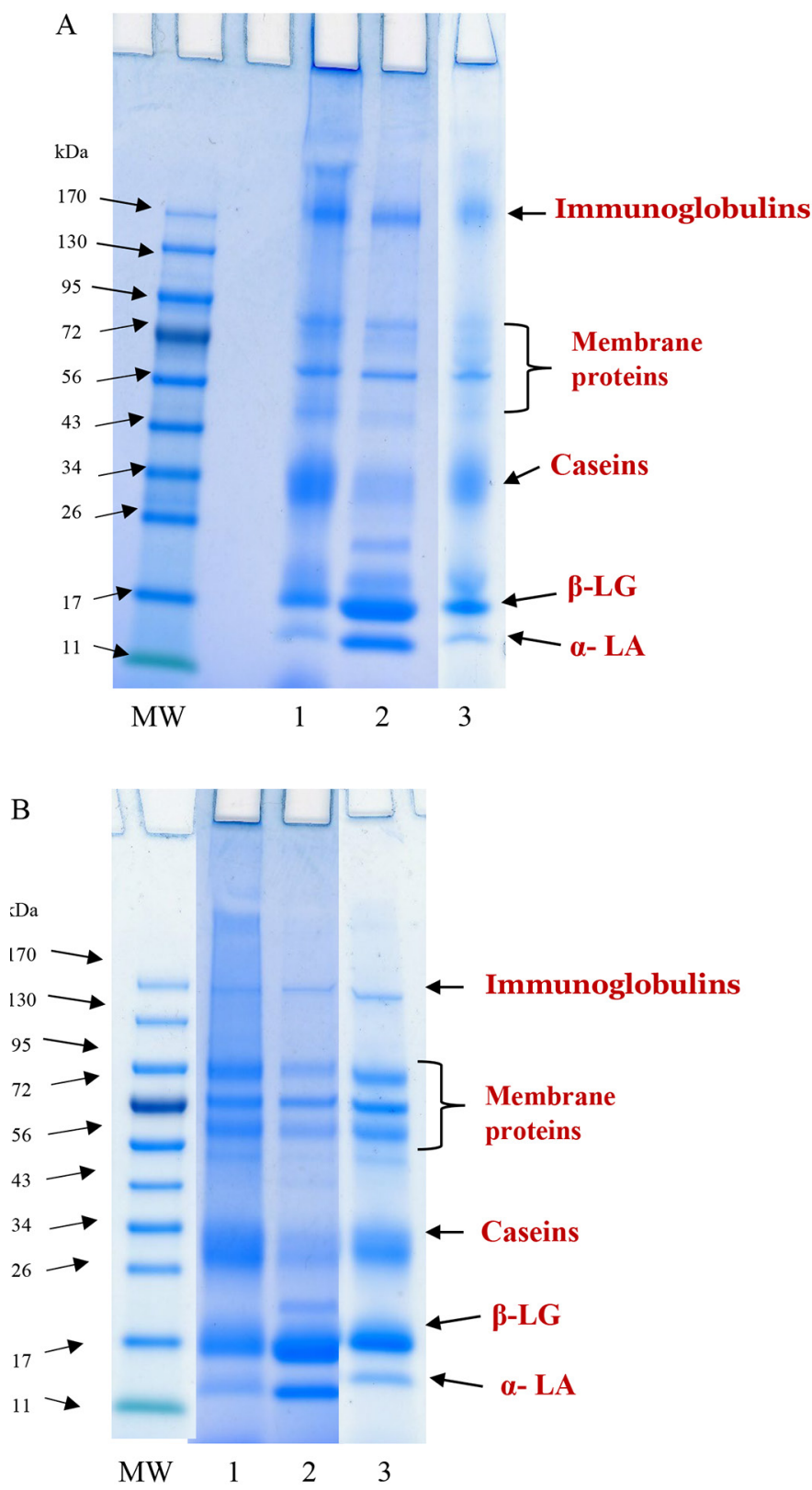

Figure 5. Sodium dodecyl sulfate-PAGE profiles of rehydrated whey protein phospholipid concentrate (WPPC) solution, liquid WPPC, and microfiltration (MF) feed for whey protein isolate production. Lane $\mathrm{MW}=$ molecular weight marker; lane $1=$ rehydrated WPPC solution; lane $2=$ MF feed; lane $3=$ liquid WPPC under (A) nonreducing, and $(\mathrm{B})$ reducing conditions.

$21 \%$ after the addition of $30 \mathrm{~m} M$ Ca. Previous studies of thermocalcic aggregation performed on cheese whey resulted in a higher precipitation of PL. Maubois et al. (1987) found a $70 \%$ reduction in phosphorus content in the supernatant after the thermocalcic process, and Rombaut and Dewettinck (2007) were successful in precipitating about $90 \%$ of the PL with the same treatment. Both studies were undertaken at a temperature of 


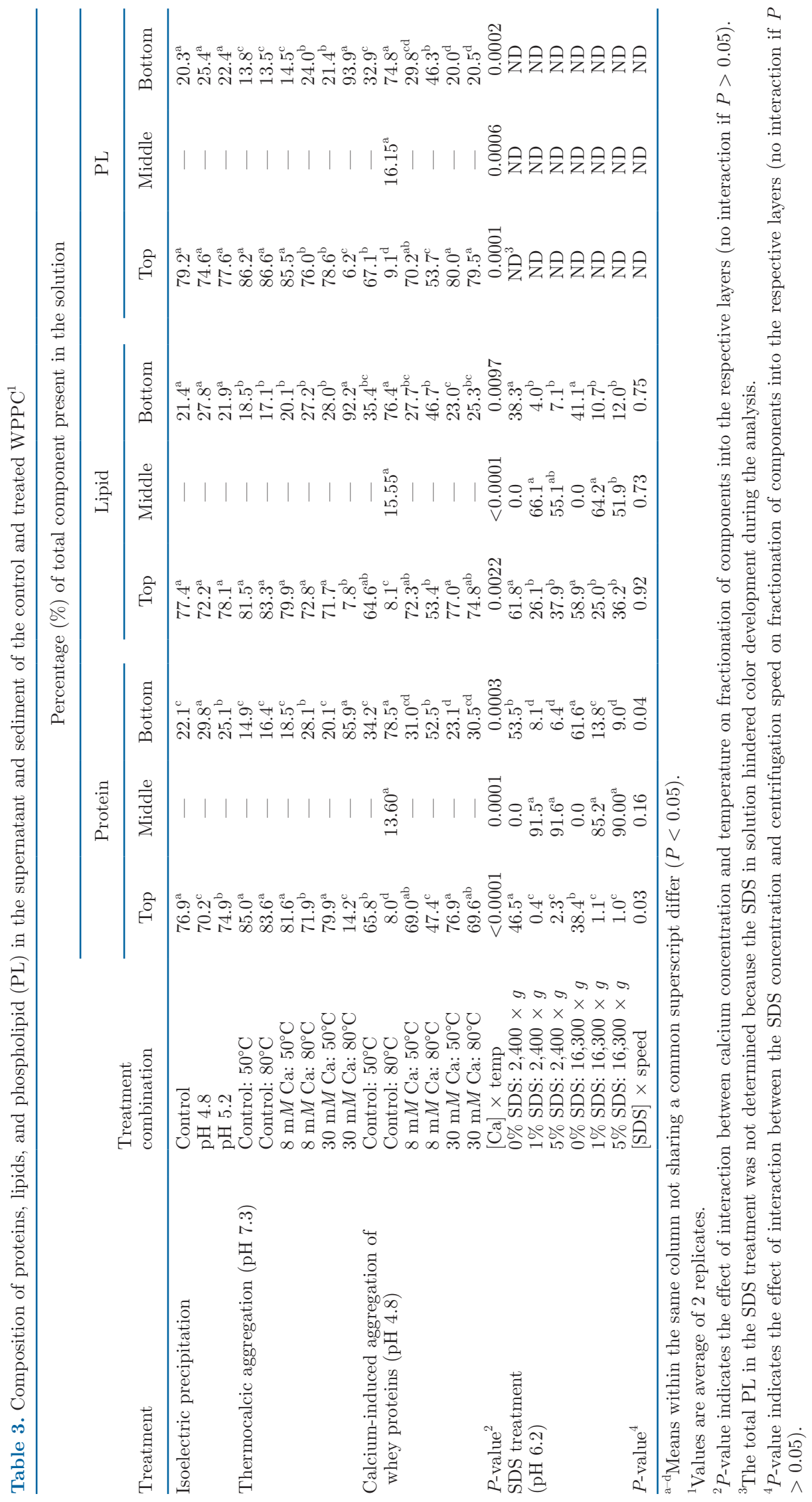


$50^{\circ} \mathrm{C}$. At $80^{\circ} \mathrm{C}$ and high calcium levels $(30 \mathrm{mM})$, about $90 \%$ of PL was sedimented along with about 85 and $92 \%$ of proteins and lipids, respectively. With both the temperatures and calcium levels, similar proportions of PL, protein, and lipids were separated in the layers.

Thermocalcic aggregation treatment was therefore not successful in selectively precipitating the PL in our sample. This may be due to the presence of high levels of denatured proteins in WPPC. In previous studies, most cheese whey samples had very low amounts of denatured proteins. Thus, when calcium salts were added at $50^{\circ} \mathrm{C}$ in the whey treatment, the calcium complexed with the PL and denatured proteins, thereby precipitating and sedimenting both of them. Maubois et al. (1987) reported an 11\% reduction in the nitrogen content of whey supernatant with the thermocalcic process. The proteins that were precipitated might include the lipoproteins, MFGM proteins, and whey proteins. Because our WPPC sample had very high amounts of insoluble or denatured proteins, this thermocalcic process was not suitable for separating the PL from insoluble proteins (as there was an extensive sedimentation of denatured proteins along with precipitated PL).

Figures 6 and 7 shows the SDS-PAGE profiles of WPPC supernatant (lanes 3, 5, and 7) and sediments (lanes 4,6, and 8; i.e., top and bottom layers obtained after thermocalcic aggregation treatment), with and without the reducing agent, and at 50 and $80^{\circ} \mathrm{C}$, respectively. The WPPC samples contained whey proteins, MFGM protein, and CN. Under nonreducing conditions (Figure 6a), a band was observed around $150 \mathrm{kDa}$ in all the samples, which we assume was IgG. Under reducing conditions, this band disappeared into light $(\sim 25$ $\mathrm{kDa})$ and heavy $(\sim 50 \mathrm{kDa})$ chain bands, presumably as the disulfide linkages between the $\operatorname{IgG}$ chains were disrupted as reported by Kinghorn et al. (1995) and seen in Figure 6b. Under nonreducing conditions, large unresolved aggregates were observed in all samples at the top of the gel (Figure 6a). At $50^{\circ} \mathrm{C}$, it was observed that the some of the MFGM proteins, $\beta-\mathrm{LG}$, and $\operatorname{IgG}$ were complexed or denatured (by comparing the increased intensity in the reducing conditions compared with nonreducing conditions; Figure 6).

After heat treatment at $80^{\circ} \mathrm{C}$ under nonreducing conditions, no band was observed at around $150 \mathrm{kDa}$ (Figure 7a). This complexation between MFGM proteins, $\beta-\mathrm{LG}$, and $\operatorname{IgG}$ (and possibly $\alpha-\mathrm{LA}$ ) increased at $80^{\circ} \mathrm{C}$ (Figure $7 \mathrm{a}$ ), and reducing conditions disrupted some of these complexes as the intensity of the bands for these components increased (Figure 7b). An intense band of unresolved material (on top of the stacking gel) was present in the $80^{\circ} \mathrm{C}$ gel, even under reducing conditions as shown in Figure $7 \mathrm{~b}$. This indicated that the proteins were complexed through some type of interac- tions other than disulfide bonding. Overall, there were no major differences in the type of proteins present in the top and bottom layers with different calcium concentrations. All the main proteins were present in each of the layers.

Calcium-Induced Aggregation of Whey Proteins at $p H$ 4.8. The medium-density fraction, along with the low-density fraction, was considered as the top layer, except for the control solution at $80^{\circ} \mathrm{C}$ where the 3 layers could be separated. The interaction between calcium levels and temperature for the fractionation of each of the components (proteins, fat, and PL) was determined by performing a 2-way ANOVA. As seen in Table 3, the interaction was significant for the precipitation of proteins $(P<0.05)$. The amount of proteins that sedimented decreased with an increase in calcium levels, and this effect was more obvious at $80^{\circ} \mathrm{C}$ than at $50^{\circ} \mathrm{C}$. At $50^{\circ} \mathrm{C}$, about $34 \%$ of the protein sedimented in the control sample, but at $80^{\circ} \mathrm{C}$, about $79 \%$ of the
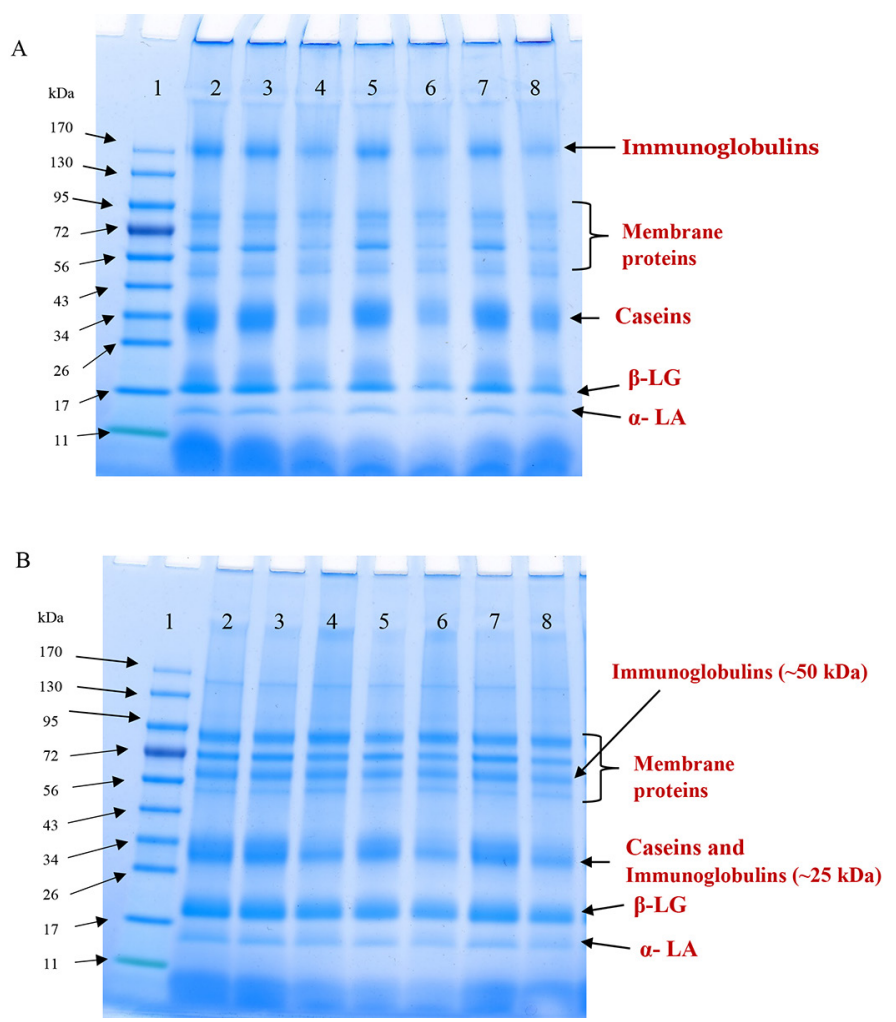

Figure 6. Sodium dodecyl sulfate-PAGE gel images of different fractions obtained from whey protein phospholipid concentrate (WPPC) sample before and after thermocalcic aggregation treatment $\left(50^{\circ} \mathrm{C}\right)$. Lane $1=$ molecular weight marker $(\mathrm{kDa})$; lane $2=$ reconstituted WPPC before centrifugation; lanes 3 and $4=$ top and bottom layer of control sample $\left(50^{\circ} \mathrm{C}\right.$, no Ca added) obtained after centrifugation; lanes 5 and $6=$ top and bottom layer $\left(50^{\circ} \mathrm{C}, 8 \mathrm{mM} \mathrm{Ca}\right)$ of sample after centrifugation; lanes 7 and $8=$ top and bottom layer $\left(50^{\circ} \mathrm{C}, 30\right.$ $\mathrm{m} M \mathrm{Ca}$ ) of sample after centrifugation under (A) nonreducing, and (B) reducing conditions. 
proteins sedimented. Increasing the calcium levels to $30 \mathrm{~m} M$ reduced the protein levels in the sediment to 23 and $30 \%$, at 50 and $80^{\circ} \mathrm{C}$, respectively. This variation in the protein sedimentation can be explained by changes in protein interactions under the different conditions of calcium and temperature. Near the isoelectric point, with no calcium added, the electrostatic attraction between the protein molecules should be at a maximum. Hydrophobic interactions are also stronger at higher temperatures. Hence, these combined forces at $80^{\circ} \mathrm{C}$ caused more of the proteins to precipitate $(\sim 78 \%)$. With an increase in the added calcium chloride concentration, there was less sedimentation of protein, which could be due to the increase in ionic strength, which reduced electrostatic attraction between the proteins.
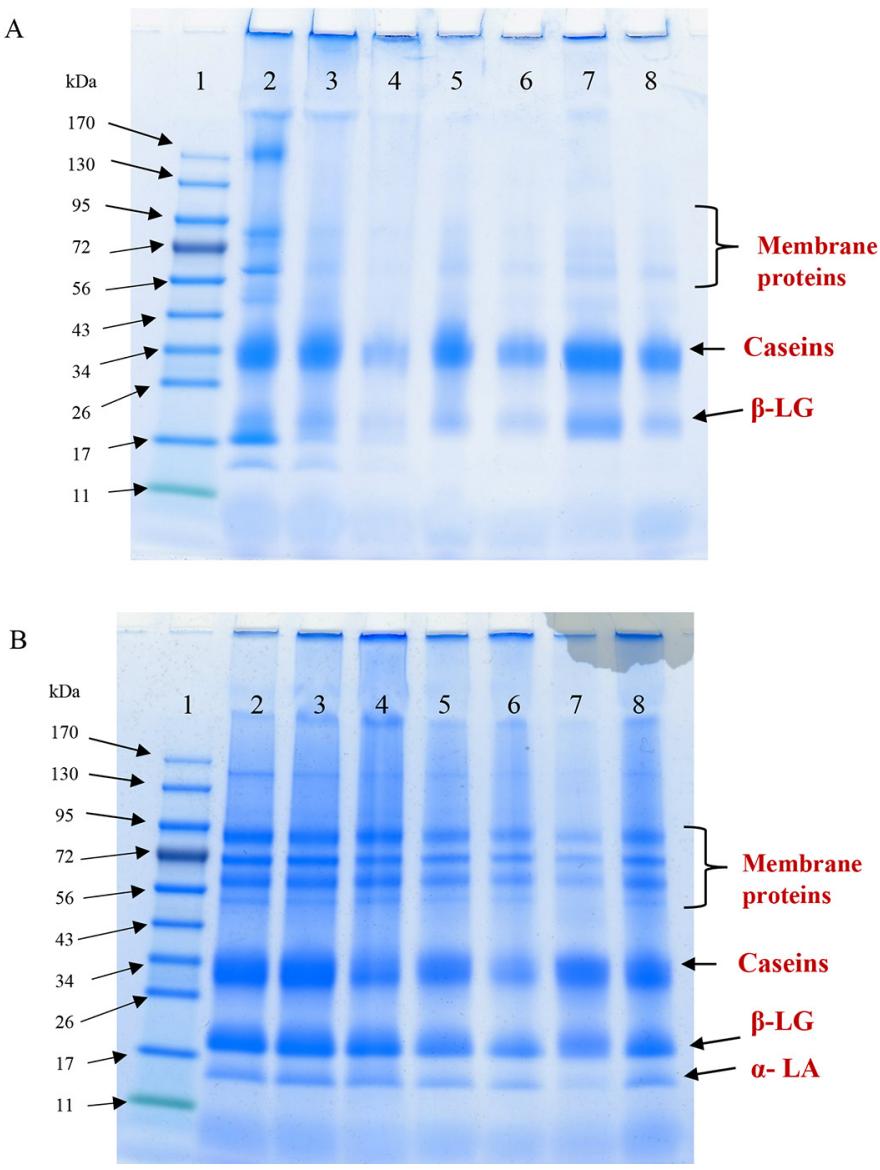

Figure 7. Sodium dodecyl sulfate-PAGE gel images of different fractions obtained from the whey protein phospholipid concentrate (WPPC) sample before and after thermocalcic aggregation treatment $\left(80^{\circ} \mathrm{C}\right)$. Lane $1=$ molecular weight marker $(\mathrm{kDa})$; lane $2=$ reconstituted WPPC before centrifugation; lanes 3 and $4=$ top and bottom layer of control sample $\left(80^{\circ} \mathrm{C}\right.$, no Ca added) obtained after centrifugation; lanes 5 and $6=$ top and bottom layer $\left(80^{\circ} \mathrm{C}, 8 \mathrm{mM} \mathrm{Ca}\right)$ of sample after centrifugation; lanes 7 and $8=$ top and bottom layer $\left(80^{\circ} \mathrm{C}, 30\right.$ $\mathrm{m} M \mathrm{Ca}$ ) of sample after centrifugation with (A) nonreducing and (B) reducing conditions.
Lucey and Singh (1997) showed that increasing the ionic strength in acid gels $(\mathrm{pH} \sim 4.8)$ decreased aggregation and gelation due to electrostatic charge screening.

Calcium levels and temperature also had a significant effect $(P<0.05)$ on precipitating the lipids and PL in the solutions (Table 3 ). With changes in calcium levels and temperatures, the lipids and PL fractionated in similar proportions to the proteins. For example, at $80^{\circ} \mathrm{C}$, the protein concentration in the control sediment was $78 \%$, whereas the lipid and PL proportions (in the sediment) were 76 and $75 \%$, respectively. Therefore, we were not able to successfully separate the proteins from the lipids with this treatment. The SDS-PAGE profiles were performed on the WPPC supernatants, and sediments obtained with this treatment and similar results were observed as in the thermocalcic aggregation treatment (Supplemental Figures S1 and S2; http://digital .library.wisc.edu/1793/82259).

Effect of SDS Concentration and Centrifugation Speed on the Separation of Fat from Proteins. The WPPC solution fractionated into 3 layers after centrifugation for the SDS treatment. The SDS treated samples had a clear milky fat layer compared with the control, which only had broken fragments of fat as shown in Figure 8. The fat layer obtained after SDS treatment was also analyzed for protein and fat content to observe the amount of free fat separated. The amount of PL present in the fat layer could not be quantified after this treatment, as the SDS in the solution hindered the color development during the total $\mathrm{PL}$ analysis.

A 2-way ANOVA was performed to observe any interaction between the SDS concentration and the centrifugation speed on the separation of the protein and fat between the layers (Table 3). The SDS concentration did not have a significant effect on increasing the amount of fat fractionated in the top layer. There was no clear fat layer observed in the control sample (0\% SDS) at both speeds. Hence, the supernatant, along with the broken fragments of fat in the fat layer, was considered as the top layer in the control sample. The fat content in the top layer was similar for both centrifugation speeds. With the use of $1 \%$ SDS, about $25 \%$ of the fat fractionated in the top layer. Increasing the SDS concentration to $5 \%$ increased the fat content in the top layer to around $37 \%$. The interaction between centrifugation speed and SDS concentration was not significant $(P>0.05)$, as shown in Table 3. These results showed that about $38 \%$ of the fat in the WPPC was considered to be in the form of free fat after SDS treatment and was released with the use of 5\% SDS. Free fat, also known as nonglobular fat (the fat without MFGM), is known to float on top of solutions. Similar observations were noticed by others (Kamath and Morr, 

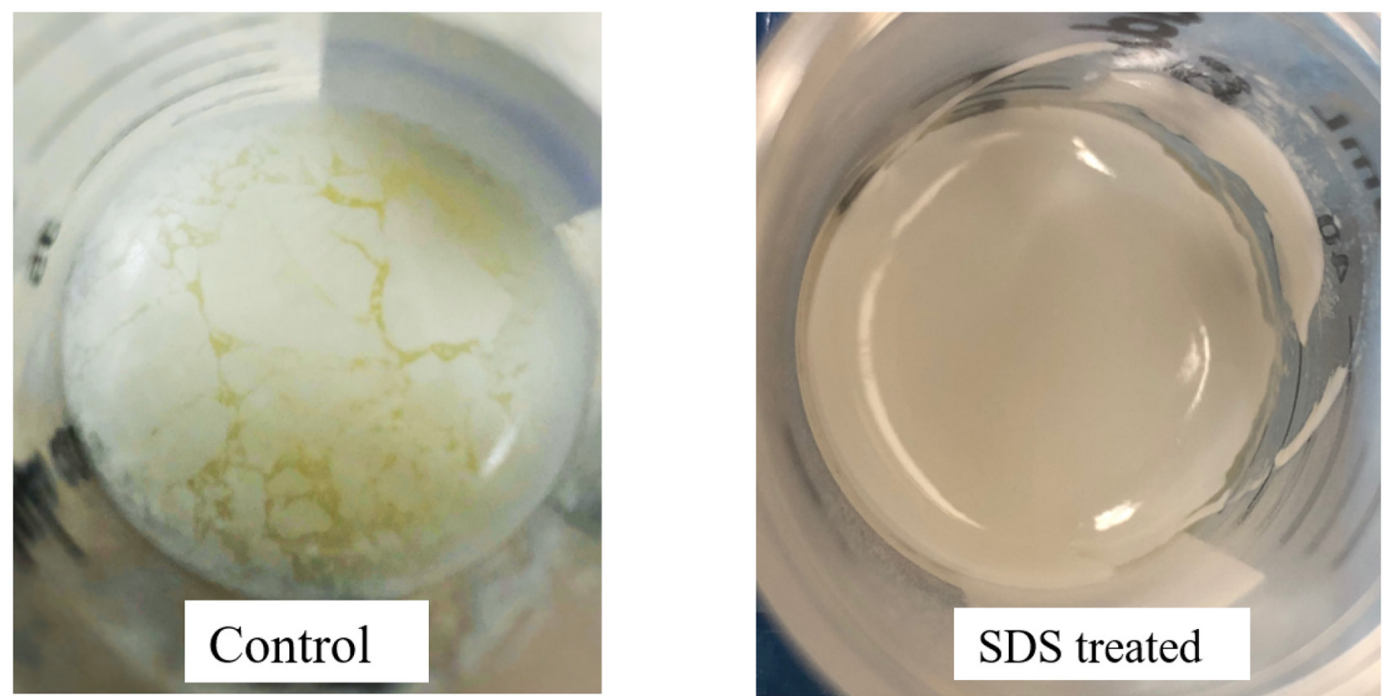

Figure 8. Images of top fat layers as observed in the control (0\% SDS) and 5\% SDS treated sample after centrifugation.

1997) when they centrifuged whey and buttermilk. The low-density fraction (top fat layer), which has a lot of neutral fat (triglycerides) as observed by Kamath and Morr (1997), was found to fractionate as a floating fat layer after centrifugation. In WPPC solutions, because most of the fat was trapped with the proteins, only some of the fat was released upon centrifugation. With SDS treatment, some of this trapped fat was released. The remaining fat in WPPC solution was apparently more closely associated with proteins, allowing it to remain in the supernatant or as a sediment, depending on their density differences.

\section{CONCLUSIONS}

The CLSM images revealed the presence of very large protein aggregates in rehydrated WPPC solutions, with most of the fat trapped inside these aggregates. This type of matrix of protein and entrapped fat is reminiscent of a high-fat spray dried product. It appeared that some of the fat may be encapsulated or trapped within the protein aggregates through the shear produced by atomization during spray drying. We were not able to easily fractionate the PL from this complicated matrix. We did see some clusters of protein surrounding the fat in CLSM images of liquid WPPC as well as a weak yield stress. This suggests that there are already interactions between the protein and fat components, even in liquid WPPC. The various chemical pretreatment methods that were applied on a bench-top scale did not successfully fractionate PL from the fat and protein components. All of these treatments had previously been successful on cheese whey but were not previously tried for WPPC. The SDS treatment helped us identify the amount of fat more closely associated with the proteins. About 35\% of the fat in WPPC was in the form of free fat that could be released by SDS treatment, suggesting that the remaining fat has some form of specific interaction with the proteins. Other fractionation methods are necessary (e.g., solvent, enzyme treatment) to isolate PL from WPPC.

\section{ACKNOWLEDGMENTS}

The authors thank National Dairy Council (Rosemont, IL) for funding this work. We also thank Agropur Inc. (Le Sueur, MN) and Grande Cheese Company (Fond du Lac, WI) for their donation of WPPC samples. The authors also thank ALS Marshfield, LLC (Marshfield, WI) for performing the compositional analysis of PL in WPPC samples. The authors have not stated any conflicts of interest.

\section{REFERENCES}

American Dairy Products Institute (ADPI). 2015. Whey protein phospholipid concentrate standard. Accessed Aug. $9, \quad 2020 . \quad$ https://www.adpi.org/Portals/0/Standards/ WheyProteinPhospholipidConcentrate_book.pdf

AOAC International. 2000. Official Methods of Analysis. 17th ed. Association of Official Analytical Chemists.

Auty, M. A. E., M. Twomey, T. P. Guinee, and D. M. Mulvihill. 2001. Development and application of confocal scanning laser microscopy methods for studying the distribution of fat and protein in selected dairy products. J. Dairy Res. 68:417-427. https://doi.org/ 10.1017/S0022029901004873.

Avalli, A., and G. Contarini. 2005. Determination of phospholipids in dairy products by SPE/HPLC/ELSD. J. Chromatogr. A 1071:185-190. https://doi.org/10.1016/j.chroma.2005.01.072. 
Barry, K. M., T. G. Dinan, B. A. Murray, and P. M. Kelly. 2016. Comparison of dairy phospholipid preparative extraction protocols in combination with analysis by high performance liquid chromatography coupled to a charged aerosol detector. Int. Dairy J. 56:179-185. https://doi.org/10.1016/j.idairyj.2016.01.022.

Bund, R. K., and R. W. Hartel. 2013. Blends of delactosed permeate and pro-cream in ice cream: Effects on physical, textural and sensory attributes. Int. Dairy J. 31:132-138. https://doi.org/10.1016/ j.idairyj.2013.02.010.

Cilla, A., K. D. Quintaes, R. Barberá, and A. Alegría. 2016. Phospholipids in human milk and infant formulas: benefits and needs for correct infant nutrition. Crit. Rev. Food Sci. Nutr. 56:1880-1892. https://doi.org/10.1080/10408398.2013.803951.

Dewettinck, K., R. Rombaut, N. Thienpont, T. T. Le, K. Messens, and J. Van Camp. 2008. Nutritional and technological aspects of milk fat globule membrane material. Int. Dairy J. 18:436-457. https:// doi.org/10.1016/j.idairyj.2007.10.014

Donovan, M., and D. M. Mulvihill. 1987. Thermal denaturation and aggregation of whey proteins. Irish J. Food Sci. Technol. 11:87-100.

Folch, J., M. Lees, and G. H. S. Stanley. 1957. A simple method for the isolation and purification of total lipids from animal tissues. J. Biol. Chem. 226:497-509. https://doi.org/10.1016/S0021 -9258(18)64849-5.

Gallier, S., D. Gragson, R. Jiménez-Flores, and D. Everett. 2010. Using confocal laser scanning microscopy to probe the milk fat globule membrane and associated proteins. J. Agric. Food Chem. 58:4250-4257. https://doi.org/10.1021/jf9032409.

Gassi, J. Y., M. Blot, E. Beaucher, B. Robert, N. Leconte, B. Camier, F. Rousseau, C. Bourlieu, J. Jardin, V. Briard-Bion, S. Lambert, G. Gésan-Guiziou, C. Lopez, and F. Gaucheron. 2016. Preparation and characterisation of a milk polar lipids enriched ingredient from fresh industrial liquid butter serum: Combination of physicochemical modifications and technological treatments. Int. Dairy J. 52:26-34. https://doi.org/10.1016/j.idairyj.2015.08.012.

Gauvin, M. P., Y. Pouliot, and M. Britten. 2018. Rennet coagulation properties of milk in the presence of MFGM fragments isolated from raw- and pasteurised-cream buttermilk. Int. Dairy J. 85:153158. https://doi.org/10.1016/j.idairyj.2018.06.006.

Huang, Z., H. Zheng, C. S. Brennan, M. S. Mohan, L. Stipkovits, L. Li, and D. Kulasiri. 2020. Production of milk phospholipidenriched dairy ingredinets. Foods 9:263. https://doi.org/10.3390/ foods 9030263

Kamath, S. R., and C. V. Morr. 1997. Recovery and composition of swiss cheese whey lipid-containing fractions. J. Agric. Food Chem. 45:4271-4274. https://doi.org/10.1021/if970597a.

Kinghorn, N. M., C. S. Norris, G. R. Paterson, and D. E. Otter. 1995. Comparison of capillary electrophoresis with traditional methods to analyse bovine whey proteins. J. Chromatogr. A 700:111-123. https://doi.org/10.1016/0021-9673(95)00117-6.

Le, T. T., J. Miocinovic, T. M. Nguyen, R. Rombaut, J. van Camp, and K. Dewettinck. 2011. Improved solvent extraction procedure and high-performance liquid chromatography-Evaporative lightscattering detector method for analysis of polar lipids from dairy materials. J. Agric. Food Chem. 59:10407-10413. https://doi.org/ 10.1021/jf200202d.

Lee, W.-J., and J. A. Lucey. 2006. Impact of gelation conditions and structural breakdown on the physical and sensory properties of stirred yogurts. J. Dairy Sci. 89:2374-2385. https://doi.org/10 .3168/jds.S0022-0302(06)72310-4.

Levin, M. A., K. J. Burrington, and R. W. Hartel. 2016a. Whey protein phospholipid concentrate and delactosed permeate: Applications in caramel, ice cream, and cake. J. Dairy Sci. 99:6948-6960. https://doi.org/10.3168/jds.2016-10975.
Levin, M. A., K. J. Burrington, and R. W. Hartel. 2016b. Composition and functionality of whey protein phospholipid concentrate and delactosed permeate. J. Dairy Sci. 99:6937-6947. https://doi.org/ $10.3168 /$ jds.2016-10974.

Lucey, J. A., and H. Singh. 1997. Formation and physical properties of acid milk gels: A review. Food Res. Int. 30:529-542. https://doi .org/10.1016/S0963-9969(98)00015-5.

Maubois, J. L. 1984. Separation, extraction, and fractionation of milk protein components. Le Lait, INRA. 64:485-495.

Maubois, J. L., A. Pierre, J. Fauquant, and M. Piot. 1987. Industrial fractionation of main whey proteins. Bull. Int. Dairy Fed. 212:154-159.

Morr, C. V., and E. Y. W. Ha. 1993. Whey protein concentrates and isolates: Processing and functional properties. Crit. Rev. Food Sci. Nutr. 33:431-476. https://doi.org/10.1080/10408399309527643.

Nguyen, H. T. H., L. Ong, C. Lefèvre, S. E. Kentish, and S. L. Gras. 2014. The microstructure and physicochemical properties of probiotic buffalo yoghurt during fermentation and storage: a comparison with bovine yoghurt. Food Bioprocess Technol. 7:937-953. https://doi.org/10.1007/s11947-013-1082-z.

Pelegrine, D. H. G., and C. A. Gasparetto. 2005. Whey proteins solubility as function of temperature and $\mathrm{pH}$. Food Sci. Technol. 38:77-80. https://doi.org/10.1016/j.lwt.2004.03.013.

Price, N., T. Fei, S. Clark, and T. Wang. 2018. Extraction of phospholipids from a dairy by-product whey protein phospholipid concentrate using ethanol. J. Dairy Sci. 101:8778-8787. https://doi.org/ $10.3168 /$ jds.2018-14950.

Riou, E., P. Havea, O. McCarthy, P. Watkinson, and H. Singh. 2011. Behavior of protein in the presence of calcium during heating of whey protein concentrate solutions. J. Agric. Food Chem. 59:13156-13164. https://doi.org/10.1021/jf203610k.

Rombaut, R., and K. Dewettinck. 2006. Properties, analysis and purification of milk polar lipids. Int. Dairy J. 16:1362-1373. https:// doi.org/10.1016/j.idairyj.2006.06.011.

Rombaut, R., and K. Dewettinck. 2007. Thermocalcic aggregation of milk fat globule membrane fragments from acid buttermilk cheese whey. J. Dairy Sci. 90:2665-2674. https://doi.org/10.3168/jds .2006-711.

United States Dairy Export Council (USDEC). 2018. U. S. Whey protein isolate production 2012-2016. Accessed Jul. 15, 2021. https:/ /www.thinkusadairy.org/products/whey-protein-and-ingredients/ why-us-whey

Vaghela, M., and A. Kilara. 1996. Lipid composition of whey protein concentrates manufactured commercially and in the laboratory. J. Dairy Sci. 79:1172-1183. https://doi.org/10.3168/jds.S0022 $-0302(96) 76471-8$.

Walstra, P., and J. J. de Graaf. 1962. Note on the determination of the phospholipid content of milk products. Neth. Milk Dairy J. 16:283-287.

Zhu, D., and S. Damodaran. 2013. Dairy lecithin from cheese whey fat globule membrane: Its extraction, composition, oxidative stability, and emulsifying properties. J. Am. Oil Chem. Soc. 90:217-224. https://doi.org/10.1007/s11746-012-2152-5.

\section{ORCIDS}

A. V. Swaminathan (®) https://orcid.org/0000-0003-2751-731X

M. S. Molitor @ https://orcid.org/0000-0001-5312-1488

K. J. Burrington (ㄱ https://orcid.org/0000-0003-0238-0038

D. Otter $\odot$ https://orcid.org/0000-0002-2275-8141

J. A. Lucey ㄴ) https://orcid.org/0000-0002-8838-5130 